\title{
Geographical and Temporal Dimensions of Bulgarian Attitudes towards the Rural Environment
}

\author{
CHAD STADDON* \\ University of the West of England, Bristol \\ STEFAN GENCHEV \\ Bulgarian Academy of Sciences, Sofia
}

\begin{abstract}
This paper explores certain dimensions of the transformation since 1989 in attitudes towards the environment in one largely rural locality of southwest Bulgaria. There is something of a paradox apparent in rural attitudes and behaviours to the environment: nakedly expropriative on the one hand whilst simultaneously deeply concerned and celebratory on the other. Exploration of this apparent paradox is the primary objective of this paper. The authors present findings from a decennial survey initiative focusing on environmental attitudes and behaviours in a mountainous Bulgarian locality. Results from 1999 and 2011 are presented side by side with a view to identifying temporal and (local) geographical trends in environmental views, attitudes, opinions and behaviours. An analytical perspective, drawing on political ecology and post-structural social theory, is developed and applied.
\end{abstract}

Keywords: environmental attitudes, rural communities, human geography, cognitive dissonance, transition, Bulgaria

Sociologický časopis/Czech Sociological Review, 2013, Vol. 49, No. 3: 375-401

\section{Introduction}

This paper explores certain dimensions of the transformation since 1989 in attitudes towards the environment in one largely rural locality of southwest Bulgaria. While there has been much attention paid to general and national-scale issues in post-communist environmental reconstruction [e.g. Carter and Turnock 2002; Kostova Vladimirova and Radoynovska 2011; Petersen 1993], relatively little research exists that examines the specifically local impacts of broader post-communist transformational processes. Environmental issues especially have tended to be treated at the national scale and through the lenses of either policy reform [Moldan and Klarer 1997], overall environmental quality assessment [Stanners and Bourdeau 1995] or general 'environmental culture' [Mirovitskaya 1998; Oldfield 2006]. Still less has been said—outside of anthropology [e.g. Cellarius 2004;

\footnotetext{
* Direct all correspondence to: Chad Staddon, Department of Geography and Environmental Management, University of the West of England, Bristol, UK, e-mail: Chad.Staddon@ uwe.ac.uk; Stefan Genchev, Department of Geography, National Institute of Geophysics, Geodesy and Geography, Bulgarian Academy of Sciences, e-mail: sgenchev@uco.edu.
}

(C) Sociologický ústav AV ČR, v.v.i., Praha 2013 
Burawoy and Verdery 1999; Bridger and Pine 1998]—about how environmental attitudes and behaviours are changing in rural localities; those out of the way places usually neglected by analysts interested in plumbing the 'national mood' or metropolitan cultures [but see Petrova, Cihar and Bouzarovski 2011]. In periods of economic turmoil—and Bulgaria has certainly experienced much of that since 1989-these behavioural interactions tend towards direct expropriation of the 'use values' from local hinterlands (e.g. firewood, hunting) and also the 'exchange values' inherent in items like mushrooms and commercial timber that are saleable for ready cash, often on the black market [Cellarius 2004; Staddon 1999, 2001]. Coupled with this is a more 'utilitarian' attitude towards nature, seeing it as a larder to be plundered more or less at will and according to need. Running counter to this apparent utilitarian attitude there is, however, also an abiding 'love of nature' in Bulgaria, which expresses itself in a resilient celebration of nature (especially as 'priroda' rather than the more technical 'okolna sreda') in poetry, music and popular attitudes and practices towards the natural world (e.g. celebrations of civil and religious holidays in natural surroundings). Thus there is something of a paradox apparent in rural attitudes and behaviours to the environment: nakedly expropriative on the one hand whilst simultaneously deeply concerned and celebratory on the other.

Exploration of this apparent paradox is the primary objective of this paper. We present findings from a decennial survey initiative focusing on environmental attitudes and behaviours in a mountainous Bulgarian locality. Results from 1999 and 2011 are presented side by side with a view to identifying temporal and (local) geographical trends in environmental views, attitudes, opinions and behaviours. Other papers have reported on the 1999 survey [Staddon 2001; Staddon and Turnock 2001], on a similar survey conducted in 1999 in Poland with colleagues from Wroclaw University [Staddon and Grykień 2007, 2009], and on parallel but wholly separate studies of localities elsewhere in Central and Eastern Europe and the former Soviet Union [Burawoy and Verdery 1999; Petrova, Cihar and Bouzarovski 2011]. One of the unique features of this survey is that it is embedded in a long-term study of socio-environmental transformations in one region of southwest Bulgaria and seeks to contribute to a growing dataset that also includes a large repository of interviews, statistical data, case studies and ethnographic and historical material. We argue that this sort of multi-method approach, especially when pursued over time and across multiple local case studies, can yield a wealth of information about the ways in which people create complex sorts of attachments to place, attachments that are at once economic, political, social and cultural. Lest we lapse into thinking that such attachments are in the first instance to physical spaces and places, Low and Altman [1992: 7] point out that '[p]laces are ... repositories and contexts within which interpersonal, community, and cultural relationships occur, and it is to those social relationships, not just the place qua place, to which people are attached'. And geographer Yi-Fu Tuan reminds us that such attachments are temporal as well as spatial: 'What begins as undifferen- 
tiated space becomes place as we get to know it better and endow it with value.' [1977: 6] We believe that it is precisely in the complexity of such multi-faceted attachments that the internal logic of our apparent paradox can be found.

How are we to satisfactorily analyse our growing dataset of qualitative and quantitative materials? There are many options and so it behooves us to consider, at least briefly, a few of them before nailing our own analytical colours to the mast. Within environmental psychology it is common to analyse environmental behaviours from the point of view of 'values, beliefs and norms' or 'VBN' [Stern 2000]. While 'VBN' models have been found to explain behaviour more completely than other factors such as socio-demographics [Diamantopolous et al. 2003] we argue that contextual factors are likely to be at least as important, not least because any given attitude may have multiple underlying drivers, social, cultural, political, economic, which only approximately triangulate onto the measured value or attitude. Within environmental sociology and history it is common to interpret contemporary attitudes and values as products of either contemporary social position or as the logical outcome of a chain of historical processes. Thus, for example, in his Wilderness and the American Mind [1967], Roderick Nash famously argued that American (and by extension European) attitudes towards nature went from a sense of fear, and even moral outrage at its 'primordiality', to a sense of fear and oral panic at its apparent disappearance. The key historical pivot between the two master-attitudes came with the closing of the American frontier and the division of the entire earth into colonial spheres of influence in the last quarter of the 19th century. Were we to adopt this analytic for our data we would tend towards an argument based in historical or sociological immanence-i.e. Bulgarians in the Razlog Basin think a certain way about the environment because the past and its social formations compel them to. Obviously such analysis can only ever be partly correct, divorcing itself as it does from direct empirical experience with localities and assuming that there is an externally-based totality which can make sense of the welter of partial, contradictory and puzzling viewpoints that make up an active, dynamic community.

Thus, inconsistencies or cognitive dissonances that are apparent in the measured data may actually be, at least in part, artefacts of the instruments, analytical techniques themselves and the epistemological a prioris held by well-meaning social scientists. External context, that is to say local geography, is critical here inasmuch as it can foreground or background underlying different underlying drivers whose relative contribution to the measured value or attitude may then change even if the measured attribute does not appear to. Another way of putting this is to suggest, with Massey [2001: 462] that attitudes and behaviours are the complex and always contested outcomes of 'the crisscrossing of social relations, of broad historical shifts and the continually altering spatialities of the daily lives of individuals'.

An often neglected corollary of the above observation is that vertical scale hierarchies, so often assumed in social analysis (since the local is 'obviously' 
contained within the 'regional' and the 'regional' within the 'national', etc.), become almost 'flat' [Marston, Jones and Woodward 2005] when we realise just how unstable, dynamic and vexingly non-hierarchical they can be. This leads us to contend that 'local' attitudes are not merely the lowest or most immediate scale of environmental apperception or valorisation but are rather part of an epistemic moment bringing together asymmetrical power relations (over land, over other people, over things, etc.) and their expression in language into existential 'moments' through which meanings and feelings are also imbricated. This way of thinking about the co-construction of environmental meanings, attitudes and ideas can also be thought of as a sort of 'poststructuralist political ecology'. Whilst traditional political ecology, following Blaikie and Brookfield [1985] and Bryant and Bailey [1997], tends to see outcomes, such as environmental attitudes or behaviours, as mechanistic products of class relations in land resources, a poststructuralist political ecology sees those relations as also part of a process of coconstitution through which domination over people, over communities and over labour as well as the natural world is instantiated. In other papers [Staddon 2001, 2009] we have explored some of the implications of this poststructural, or 'critical' [cf. Forsyth 2003], political ecology for notions of agency and intentionality. Here we are more interested in demonstrating how a more thoroughly critical political ecology can help us to reconcile apparent contradictions in the environmental attitudes held by our Bulgarian respondents.

The 2011 survey contained 36 separate questions organised under the following headings:

- Basic respondent characteristics (gender, age, location)

- Local economic conditions and the environment

- Governance, community and the environment

- Local environmental issues

- Socio-economic status

In both 1999 and 2011 survey-takers were employed to take the surveys directly door to door. Standard Western European sampling methodologies (e.g. randomised selections from telephone directories, internet or postal surveys) were deemed inappropriate in this region and so survey-takers used a combination of random selection of households organised into face blocks and snow-ball sampling according to an overall sampling frame designed to ensure proportional representation of the four largest settlements in the Razlog Basin: Razlog, Bansko, Dobrinishte and Banya (Map 1). Surveying was done in late summer in order to take advantage of the longer days and the greater ease of travel around a region that can be more difficult to negotiate in wintertime. A total of 120 completed surveys were returned in both 1999 and 2011, comprising something like $0.5 \%$ of the total local population. The subsample replication method ('jackknifing') gives us confidence that this sample size is sufficient for at descriptive and explanatory purposes if not prediction (which was never our desire in any case). 
Analysis of such survey data presents real challenges and must be undertaken very carefully. In the first, place numerous potential sources of bias may confound attempts to interpret results including:

- Social desirability bias - where respondents may opt for choices they think portray them in a more favourable light, rather than opting for their 'true' preferences;

- Acquiescence bias - where respondents may agree with a statement simply because it seems authoritative or indeed because they don't quite understand it;

- Information bias - where respondents opt for responses related not to their own underlying attitudes or preferences but rather informed by information given by the researchers verbally or on the questionnaire itself;

- Instrument bias - linked to information bias, this can occur where a given question or series of questions unfairly 'leads' the respondent or puts her in an impossible (e.g. 'Why do you hate the environment?' as a first order question is predicated on the assumption that respondents do hate the environment);

- Learning bias - where respondents learn over the course of the survey and begin to integrate that new learning into their subsequent answers. Unless one is specifically undertaking 'deliberative research' where learning is part of the object of the exercise, such learning biases need to be carefully controlled for through elimination of unnecessary cues and data and neutral implementation of the survey.

Dealing with such difficulties within the context of a questionnaire which must be both easily comprehended and relatively brief (lest one suffer from a fourth kind of bias, response bias, related to strength of motivation to complete the questionnaire!) is quite a challenge [cf. Burton 2000; Winchester 1999]. The weather, time of day, demeanour of the surveyor and other finer details are also sources of bias. In our survey we elected to limit the number of questions asked to 36 and through pilot testing ensuring that respondents could understand them easily and answer them quickly. For these reasons in 1999 and 2011 we did not include questions employing contingent valuation (CV) methods or many questions with open-ended or narrative responses as we did in survey research undertaken in 1992 and 1993 in the Bourgas region of eastern Bulgaria. We also used trained survey takers to undertake the task of taking respondents through the questionnaire in person according to our stratified sampling method. Surveytakers were instructed to ask questions in as neutral a manner as possible and not to discuss them with respondents during the questionnaire or to respond to requests for the 'right' answers. They reported a high level of respondent interest in the initiative and relatively little difficulty with the process. Some respondents even recalled the 1999 survey and were interested in learning more about the differences between the 1999 and 2011. Very few potential respondents refused outright to participate in the study.

A further set of difficulties arises with the choice of analytical methods for this type of data. Often such data is not subjected to much more than visual de- 
piction via bar charts or tabular counts of response classes. Cross-tabulations are sometimes also used to begin to assess covariation and correlation within multivariate data sets, often with correlation coefficients such as Spearman's rank or Pearson's product moment correlation coefficients. ANOVA is also sometimes used to provide a quick check on whether different data classes/groups are similar or different with respect to a given attribute (e.g. comparing the responses of men versus women to a given closed type question). In this paper we make limited use of all of the above to explore interrelationships in the data obtained from our survey. We also go a little further, statistically speaking, reporting on attempts to construct multiple linear regression models that can explain enough of the variation in environmental attitudes and behaviours to assist with the examination of our primary research problem. This technique is a little more controversial since it involves non-interval data, but there is adequate precedent in the literature for it to be attempted here [de Vaus 2002; McCullagh 1980]. Overall though, we wish to provide more than a solely quantitative analysis of results obtained for three reasons. First, this paper marks our first attempt to explore the 2011 data and we therefore feel the need to move slowly and inductively, making frequent recourse to other data we also hold about this region. Second, the phenomena we are studying are complex and socially-constructed, implying that a purely quantitative analysis would yield at best results with an inescapable spuriousness (not least because the perfect internal validity of the measures used cannot be assumed). Third, we seek to use these results not to reduce the Razlog Basin to overly simplistic measures, but rather to open up a more ethnographic analysis of changing attitudes, values and behaviours.

For the purposes of this paper analysis of results obtained in 2011 has taken three forms. First, we seek to provide as detailed and structured a statistical presentation of results as possible, generally in direct comparison with the 1999 survey, which was in most respects identical. Side-by-side bar charts (Figures 1-6) are used extensively to provide an easily appreciated and comparative presentation of results. We also undertake a limited amount of correlation analysis (particularly with respect to probing the relationships between age and socio-economic status and expressed attitudes and behaviours), using Spearman's rank correlation coefficient and ANOVA where appropriate. Cross tabulations and pivot tables are used to further explore the relations between response patterns to different questions as is, to a limited extent, multiple regression analysis. Second, we interpret our results contextually, with reference to our deep knowledge of the region's social, economic, cultural and political history as recorded in interviews, media reviews, previous publications, etc. Third, we explore the apparent paradox at the heart of rural Bulgarians' environmental attitudes: simultaneously openly exploitative and deeply reverential.

In the next section of the paper we provide a brief introduction to the human geography of the study region. In the third section we present the results received in the 2011 survey and compare them with those obtained in 1999 and 1992. In 
the fourth section we begin to open up the data to quantitative and qualitative analysis. That is to say, we undertake some limited statistical analyses, but seek to interpret the results obtained with reference back to our detailed ethnographic material on the locality. Finally, we reflect back on the initial postulation of paradox embedded at the heart of local attitudes towards the environment in the light of the analysis presented here and consider some implications for future research.

\section{Human geography of the Razlog Basin, Bulgaria}

The Razlog Basin is an upland area (MSL, 800 metres) formed at the junction of the Pirin, Rhodope and Rila Mountain massifs and incorporating the two municipalities (obshtini) of Razlog and Bansko (see Map 1). In addition to these municipal centres, with 2012 populations of about 14000 and 12 000, respectively, there are a number of smaller settlements within the two municipalities including Banya (pop. 3000), Dobrinishte (pop. 3000), Gorno Dragleshte, Bachevo, Dolna Dragleshta and Godlevo (Map 2). The region has a long and venerable tradition within Bulgarian history; patriots such as Pasii Hilendar, Nikola Vaptsarov and Neofit Rilski were born here, and events such as the 1878-1879 Kresna-Razlog and 1903 Preobrazhenie Uprisings against the last vestiges of Ottoman rule had strong local expressions here [Crampton 1997; Bell 1977]. In a recent study Grunewald and Scheithauer [2011] suggested that extreme population fluctuations in the region can be attributed to the impact of climate volatility on harvests, with the result that the uplands particularly remained sparsely settled and under-urbanised well into the late 19th century. During the Balkan Wars the area changed hands between Greek and Bulgarian armies several times before being ceded to Bulgaria the post-First World War settlements with consequent transmigration of populations over the new frontier. ${ }^{1}$ During the interwar years (1918-1939), with Bulgaria ruled first by a peasant-agrarian movement (the BANU, led by Aleksandr Stambolyiski, assassinated in Sofia in 1923) and then a right-wing dictatorship (under Aleksandr Tsankov) which eventually allied itself with Hitler's National Socialist movement, southwest Bulgaria became something of a political and economic backwater.

During the state-socialist period (1944-1989) the region was administered chiefly in terms of the exploitation of its natural resources for industry and tourism with some ancillary workshop development as part of the 'social industries' (shivashki) policy [Begg and Pickles 1998; Staddon 1999]. Examples of the latter are the telephone switching equipment and magnetic head factories that were

\footnotetext{
1 There was barely a year between the messy end of the Second Balkan War in summer 1913 and the assassination of Archduke Ferdinand in Sarajevo in July 1914. During this interregnum the Great Powers jockeyed for position and consolidated the military alliances that would soon drag all of Europe into war.
} 
developed in Razlog and Bansko in the 1960s. Though the area has suffered severe industrial decline since 1989 and its agricultural sector has been restructured into a largely autarkic subsistence production system, it maintains at least two key profitable articulations with regional, national and international economies: natural resource extraction and tourism [Naidenova 1990; Staddon 1999; Staddon and Cellarius 2002]. Forestry and wood-processing, though much changed since 1989, continue to account for a significant proportion of net capital inflows as does quarrying for sand, gravel, marble and travertine. Other pre-existing manufacturing concerns, in clothing and shoes, have either closed or been taken over and restructured during the 1990s. Mountain tourism, with its origins in the royal hunting reserves of the late 19th century, has boomed in recent years and is quickly outstripping more traditional industries as a source of cash income and local employment. Bansko in particular has experienced a huge property development boom in recent years that has more than doubled the number of buildings in the municipality and in 2009 debuted as a venue on the FIS World Cup Ski competition circuit. Labour and skills flows also connect the southwest to the

\section{Map. 1. Study region in southwestern Bulgaria}

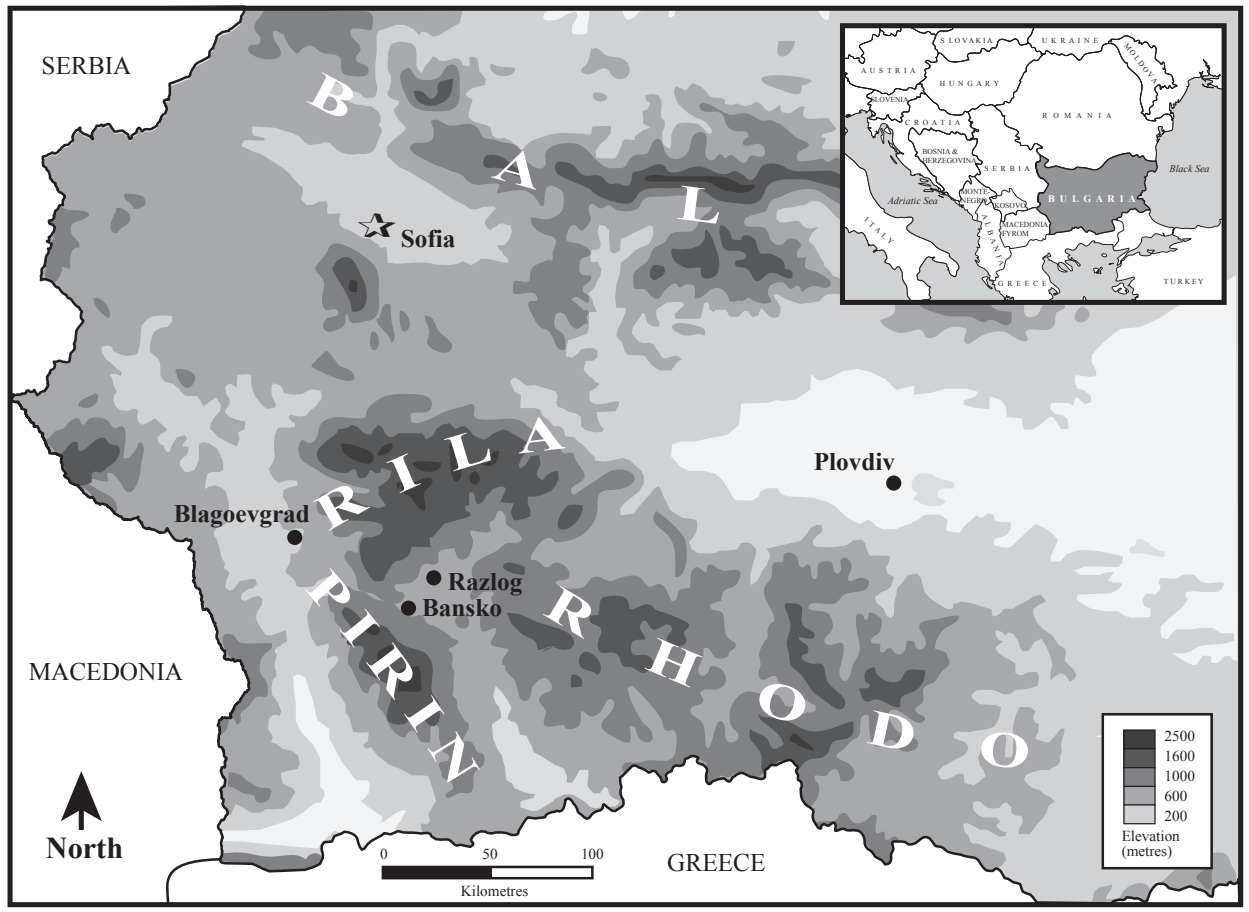

Source: Authors. 
Map 2. Razlog Basin with transport links shown

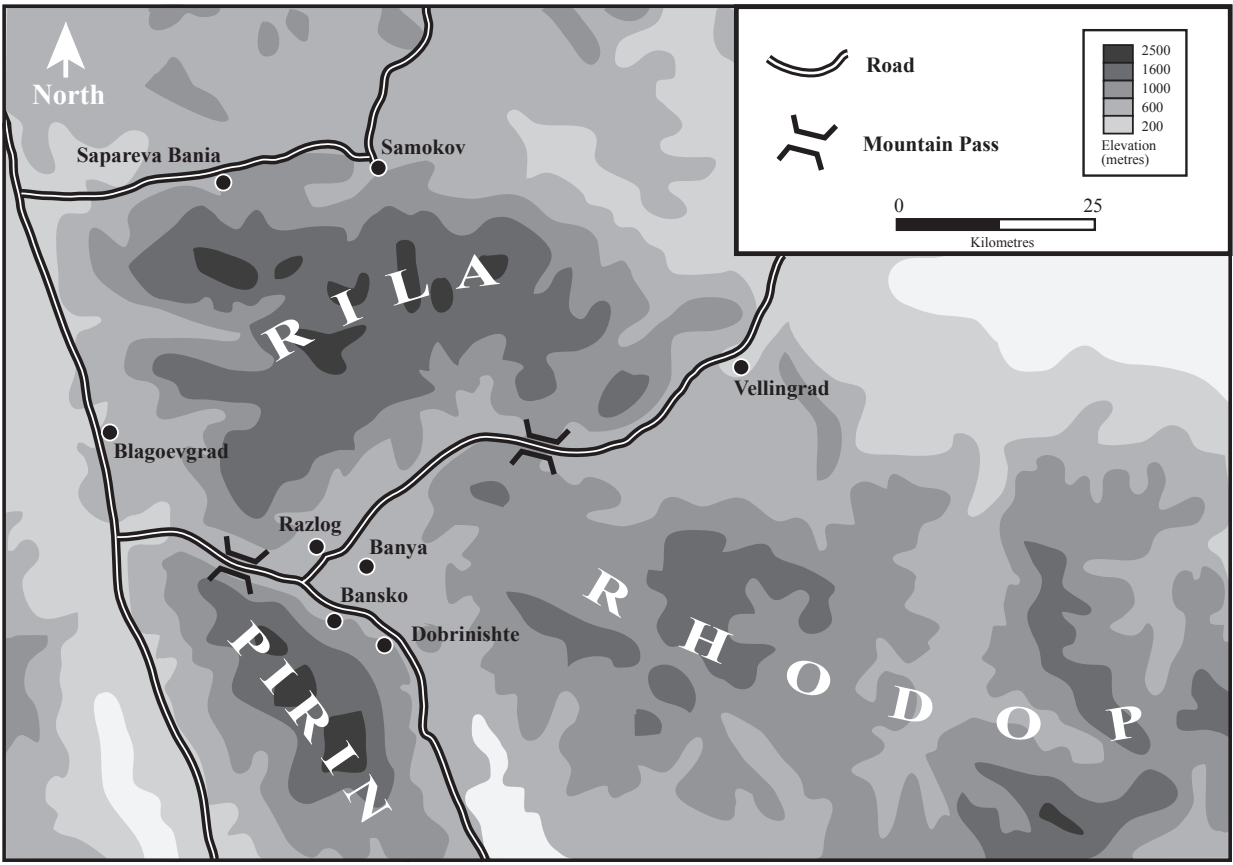

Source: Authors.

larger national economy, largely in the form of youth outmigration to the regional capital Blagoevgrad or, more likely, to the capital city Sofia. However, throughout the post-socialist period the ultimate source of surplus value has been the local environment, meaning in this case forests, rivers, minerals, flora and fauna and also pastoral and mountain landscapes.

As regards current socio-economic conditions, we note that household wages have been relatively low in both 1999 and 2011, at no greater than $60 \%$ of the national average. In 2011 the modal household wage in the Razlog Basin was 800-1000 levs/month, equivalent to about GBP 340-440 per month per household. This is, by any standard, a relatively low household wage, although there were households that received much more ( $28 \%$ of households) or much less (46\% of households). During the same period Bulgarian GDP more than doubled to 39 billion Euros, although GDP per capita rose only by about one-third [Eurostat 2013]. Even so, it is difficult for several reasons to interpret GDP per capita or money wages as a straightforward measure of socio-economic well-being, as one might in the US or the UK. Not only is there a considerable 'grey' economy, which would of course not be captured in most censuses or surveys, but we already know that many local households supply some part of their domestic consump- 
tion needs through self-supply mechanisms such as small-scale allotment style agriculture and hunting and gathering activities in local forests. Having said that, our survey results suggest that the number of households with persons engaging in hunting and gathering activities has declined since 1999. For example, only $55 \%$ now collect firewood, compared with $95 \%$ in 1999 and the number collecting herbs has fallen from $53 \%$ to $41 \%$. The only counter-trend is the rise in households collecting mushrooms (especially chanterelles, morels and cepes) from $10 \%$ to $26 \%$, no doubt precisely as a function of the thriving grey economy in such fresh comestibles. Interview respondents have told us that mushroom and herb (more limited) collection are relatively easy and enjoyable ways to make muchneeded cash. Simultaneously, the old subsistence modes of production seem to be falling by the wayside inasmuch as, for example, more local residents are supplying their firewood needs through middlemen. This is an important issue since solid fuels still provide the vast majority of heating energy, although the district government has mooted construction of a natural gas pipeline into the area.

We feel that better measures of SES can be found in the self-declared professional status of respondents and in their actual purchasing behaviours, both of which we asked about in 1999 and 2011. In 2011 20\% of respondents self-identified as professional persons, civil servants, or private business persons, with $16 \%$ identifying as unemployed. There were fewer retirees than one might expect in a rural district; the highest age of a respondent in 2011 was 64 years, compared with 70 in 1999. As regards purchases, we note that in general 2011 respondents appear better off than in 1999, with more than a third purchasing, in the last twelve months, white goods; $10 \%$ purchased a new TV system and the number travelling outside Bulgarian increased by almost 4 times to $7 \%{ }^{2}$ There is, however, a generalised trend towards those making the higher value purchases being those in the upper income brackets and having the highest levels of education. In other words, disparities in socio-economic well-being seem to be increasing over time.

\section{Environmental attitudes and behaviours-1992 to 2011}

The survey was completed during the middle fortnight in September 2011 at a time when the weather was reasonably clement and there was still daylight up to about $8 \mathrm{pm}$, giving the survey takers lots of opportunity to catch different sorts of respondents at home. The 120 respondents from whom complete surveys were taken had an average age of 34, with a high of 64 and a low of 17. There was an almost perfect split between men and women, and the stratification of the sample meant that the four settlements surveyed were surveyed proportional to their contribution to local population. This compares with a sample in 1999, which was $40 \%$ male, had an average age of 39 , and was also sampled proportional to local

2 Somewhat contradictorily the only person to claim to have purchased a new automobile also claimed to be unemployed. 
Figure 1. Percentage of households which engage in the specified collecting activities

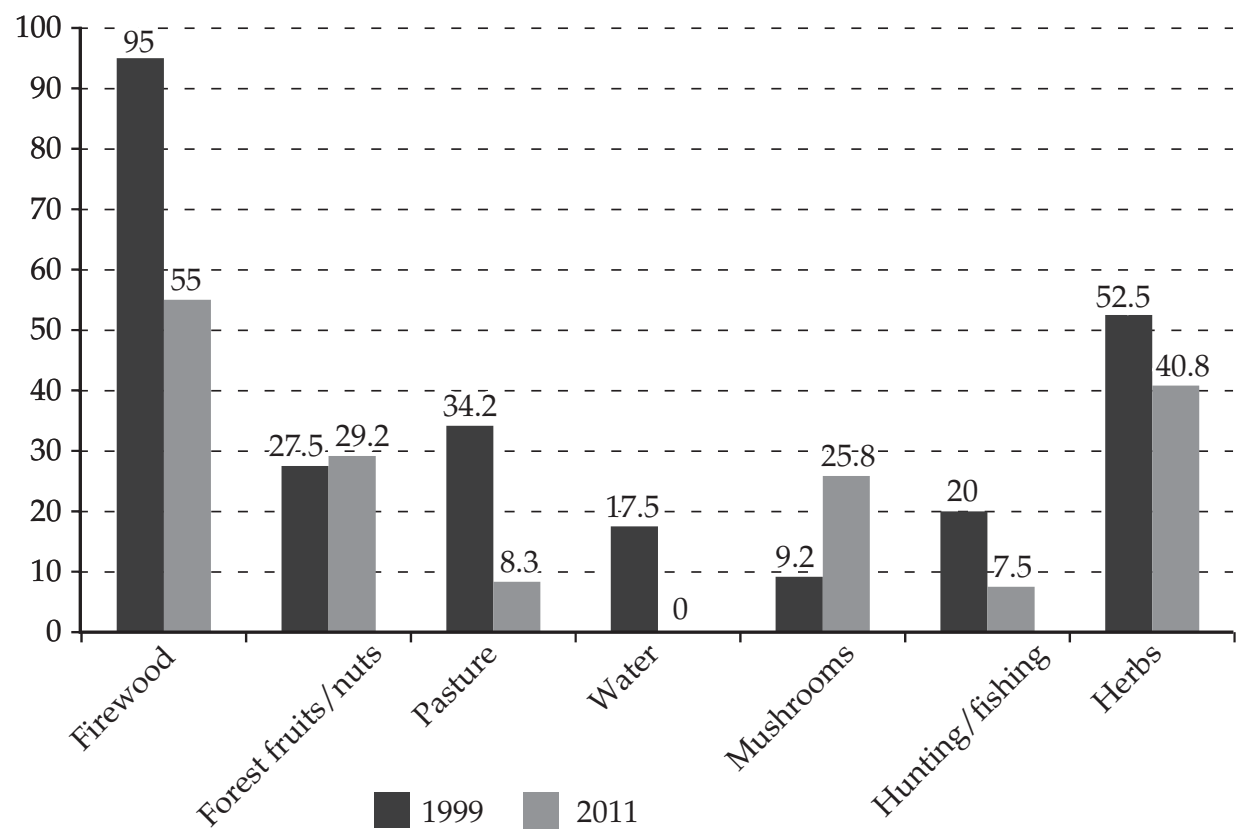

Source: Authors.

population. In other words, the two samples are fairly close with respect to age, sex and specific geographical location.

As noted elsewhere [Cellarius 2004; Staddon, Pickles and Pavlínek 1998; Grykień and Staddon 2007], low cash income levels are partly mitigated by extensive appropriation of products from local forests and a high level of small scale agriculture (aided by the agricultural land restitution of the 1990s). It is, however, the case that direct appropriations from the local hinterland appear to have decreased since 1999, as can be seen in Figure 1. Significantly fewer respondents claim to be involved in the collection of herbs or firewood, though many more are collecting mushrooms and 'forest fruits/nuts', probably because there is a ready cash market for these latter. Moreover, it is possible that whilst fewer people are engaged in collecting activities, they are better organised and are therefore collecting more-certainly we have been told by locals that collecting activities, especially for mushrooms, are becoming more specialised and are drawing in professional pickers from outside the locality. The appearance of a non-local professional picker workforce has occasionally caused conflict in the towns and villages of the Razlog Basin between locals who feel that they have rights that outsiders do not have over local resources. 
Photo 1. Google Earth image of northwestern quadrant of Razlog Basin, showing 'fishbone' effects of repeated small logging activities (above right and left of centre)

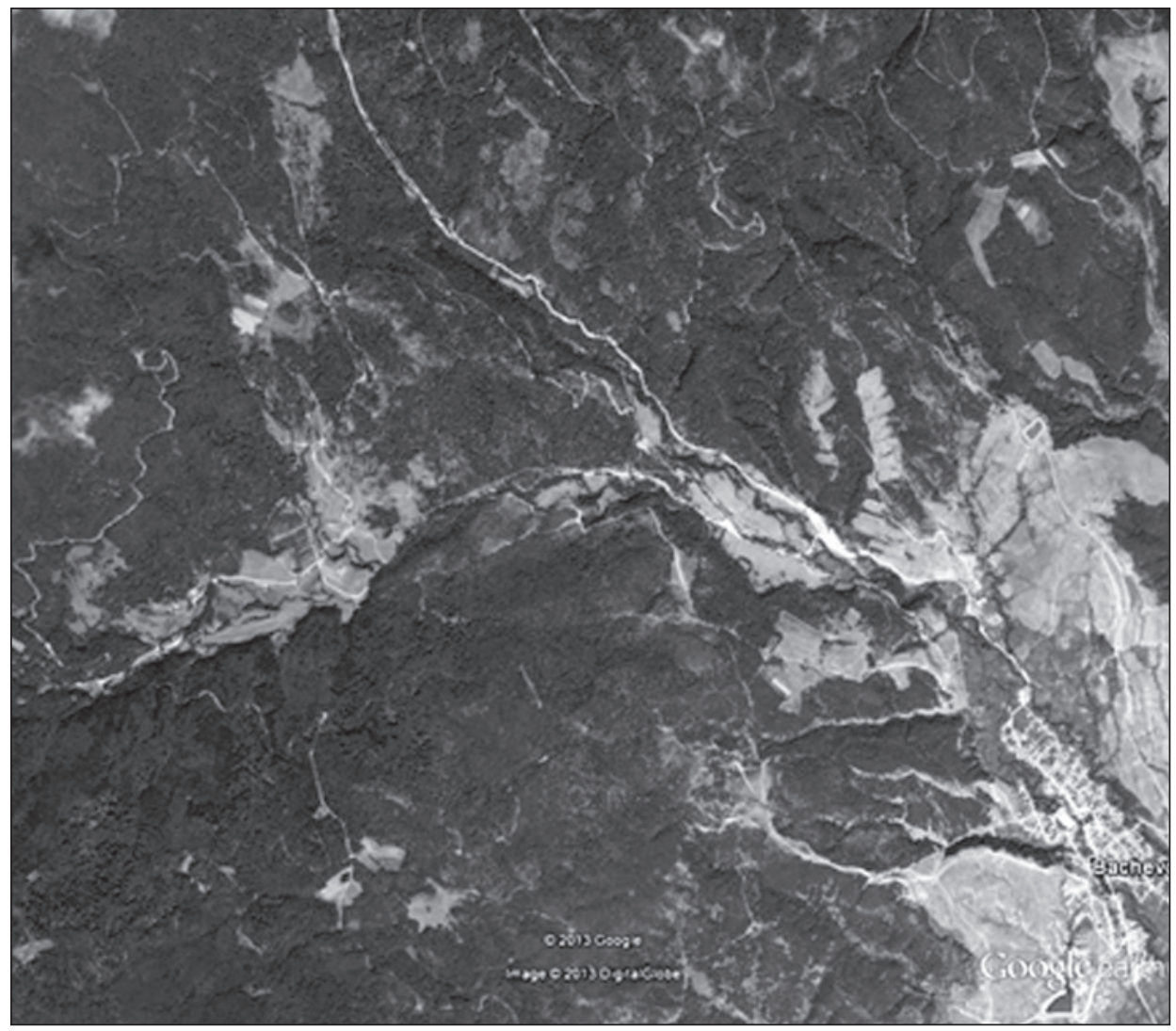

Source: Google, 2013 Digital Globe; Bachevo Area, Bulgaria, 41 55‘ 11.67“ N, 23 25`18.70“ E, Google Earth, 2 August 2004, retrieved 16 May 2013.

Elsewhere [Cellarius 2004; Staddon 2001] we have discussed the background to direct expropriation of energy sources (firewood) and foodstuffs (fish, meat, herbs) from local forests, the role of the small parcels of agricultural land in the 1990s and the specific contribution of mushroom collection (especially of Boletes and Chanterelles) to household 'consumption funds' (to use the anthropological term). One implication of these findings is that a high proportion of respondents of all ages find themselves physically in local forests and fields on a fairly regular basis. This sort of first-hand familiarity is a strong determinant of what we described in the introduction as the quality of the 'nature-love' com- 
bined with practical facility in exploitation manifest in all our research, qualitative as well as quantitative, since the early 1990s. Local people really do feel that these forests and fields are their forests and fields by virtue of their direct personal relationships with them and this clearly drives their valuation of them. As we have seen elsewhere (e.g. in earlier studies of illegal logging), direct connections to local environments offer not just what might be called 'place intimacy' (built up through numerous interactions over time as well as some degree of dependency) but also a way of legitimating actions which may be technically illegal. Place intimacy can be considered a strong form of place attachment developed, as Massey [2001: 462] tells us, through 'the continually altering spatialities of the daily lives of individuals'.

Sometimes this attachment to nature works in apparently perverse ways however. Earlier work [Staddon 2009; Staddon and Cellarius 2002] explored the patterns and underlying logic of illicit uses of the forest, especially tree theft. Through the middle of the first decade of the new century tree theft in the region was described by locals and government authorities alike in terms of a new 'Eldorado'. Trees were being taken, entirely outside official regulatory mechanisms, for at least four purposes:

- Firewood

- Charcoal making (mostly by Roma who established production camps deep inside the forest)

- Sales of raw or semi-processed timber into the construction industry (which experienced a boom until the economic crash of 2008)

- Larger scale deforestation, usually combined with smuggling outside Bulgaria

Although any given household's takings would be, in and of themselves, infinitesimal, the cumulative effect of numerous households taking firewood or mushrooms outside of official limits and license controls could be significant. ${ }^{3}$ Interestingly charcoal production in this region appears to be wholly the province of Roma families organised into peripatetic work camps operating in the May to October period. State foresters and local residents prefer to turn a blind eye to much of this activity, partly out of sympathy and partly due to the deep-seated cultural prejudice against the Roma. More significant because larger scale and locally more indiscriminate is commercial tree theft which has created some of the classic 'fishbone' patterns associated with illegal felling along official forestry roads, particularly in our study region (Photo 1) [Staddon 2009; Veen et al. 2010]. Importantly, all such activities enact place attachments of various sorts, linking actors engaged in different sorts of spatial practices and resource appropriations. For example, whilst there is a transboundary trade in Roma charcoal, much also

\footnotetext{
${ }^{3}$ There is a complex and ongoing debate in the conservation literature about the cumulative effects of numerous such acts, but the matter is as yet unresolved, particularly for mushrooms.
} 
Figure 2. 'I am optimistic about the economic outlook for my community'

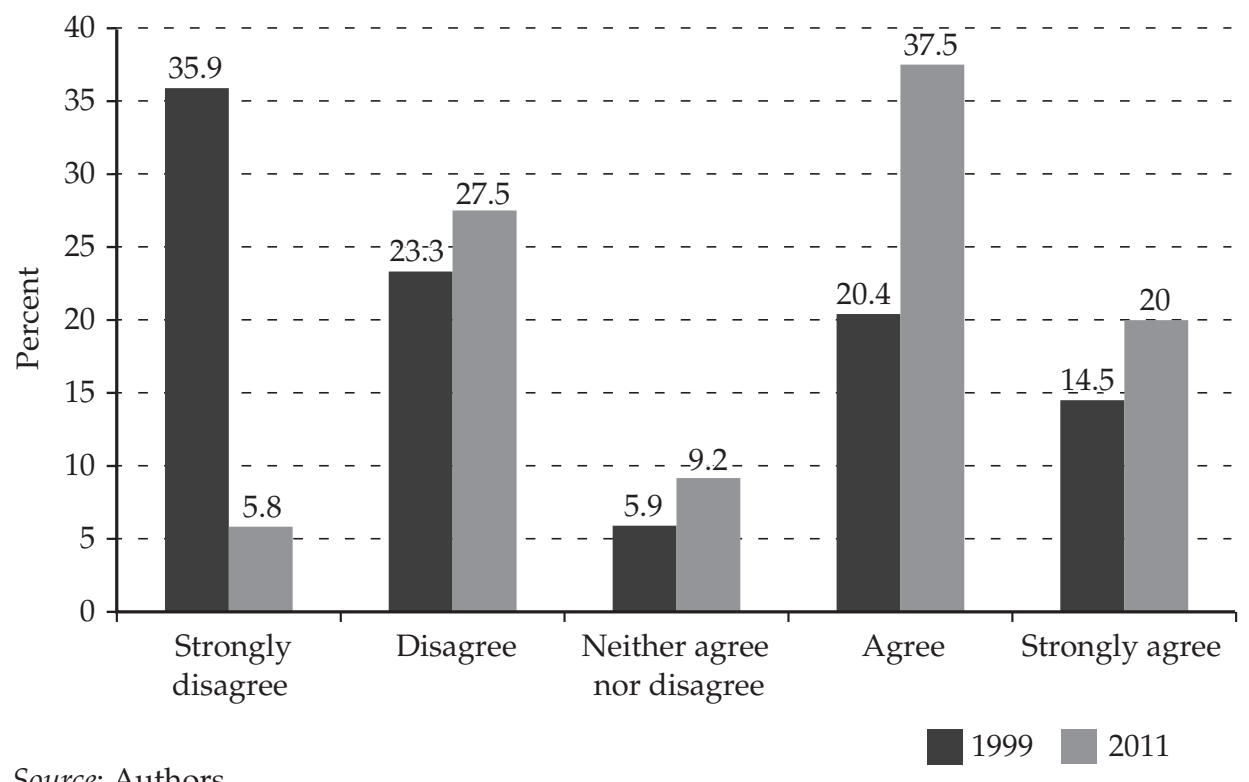

Source: Authors.

Figure 3. 'Forests in my area are in good condition'

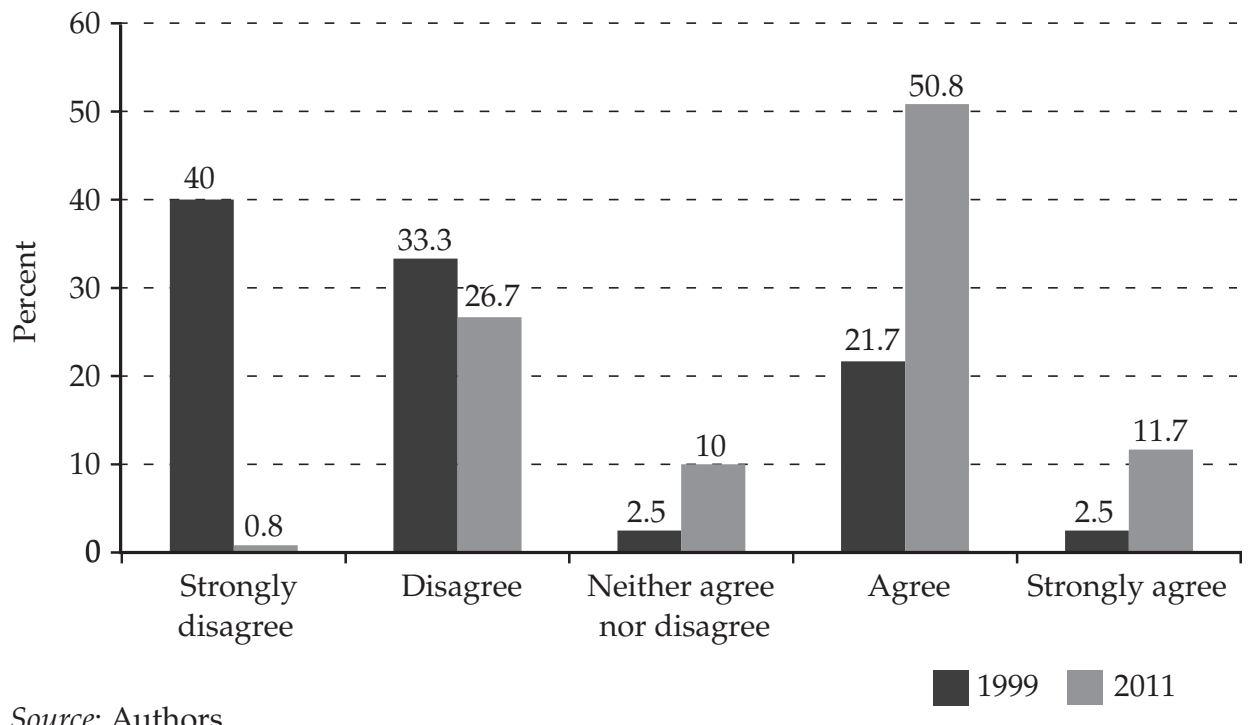

Source: Authors. 
finds its way into local markets, linking an otherwise outcast population into larger circuits of resource exploitation and capital circulation.

To the extent that the early phase of fairly haphazard expropriation from the natural environment appears to have settled down into more predictable, if arguably more locally impactful, patterns, it may be that local respondents feel less threatened, as noted in Figure 2. Respondents are considerably more optimistic overall than in 1999 and are also quite positive about the condition of local forests (Figure 3), even to the point where many respondents told us that they would like to see more forestry in their region. This may also be linked to the now well-publicised fact that, even if some localities have suffered too much cutting, overall, forest resources in the Pirin region have been growing faster than they are being harvested. People clearly feel that there is now room for both more forestry and more conservation, something embedded also in the 2010 reforms to the Forestry Act and international assessments. 'Nature tourism', however, occupies a difficult place in respondents' views, not least because the boom of resort construction in the Bansko area has created an oversupply of hotel space and an attendant huge debt hangover (Figure 4).

Interestingly, notwithstanding the difficult economic circumstances and the apparent glut of forest resources, as in 1999 respondents declined two separate

Figure 4. 'Nature tourism is the key to local economic development'

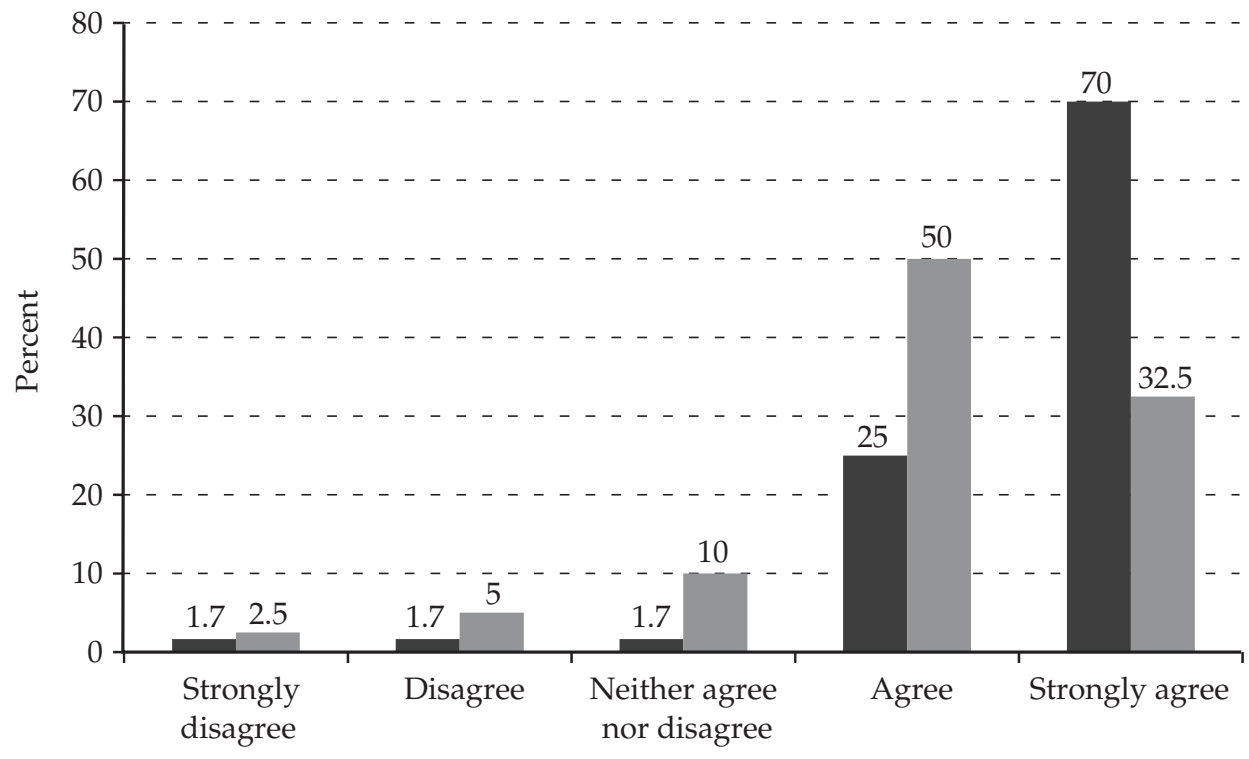

Source: Authors. 
opportunities built into the survey to support the view that the environment was a 'luxury' which would need to be 'sacrificed' in the form of higher timber exploitation rates in order to improve local economic conditions. As noted above with respect to illegal and illicit tree theft activities, local attitudes to the natural environment are much more complex than the simplistic idea that economic pressure leads to less support for conservation. As Figure 4 shows, support for the idea that 'nature tourism is the key to local economic development' declined only slightly between 1999 and 2011, though by 2011 respondents were not nearly so enthusiastic about it. Similarly, respondents' reactions to statements like:

- 'Local industry unwisely exploits the natural resources of my area'

- 'National Park Pirin is economically good for the community'

- 'Too much emphasis is already placed on protecting local forest resources'

were consistent with a sustained high level of support for the natural environment and even for conservation measures which might actually hamper local income generation. $75 \%$ of respondents were positive about the impact of National Park Pirin on the local economy compared with only $67 \%$ in 1999 . There was also stronger support for locally-based environmental management than in 1999 and far more trust in both government regulatory agencies and environmental groups. The trust issue is important inasmuch as for much of the 1990s a general sense of anarchy prevailed and Bulgarians could be forgiven for taking the view that since the state regulatory apparatus was both weak and corrupt, their own transgressions were irrelevant. Bulgarians appear to have learned to trust government more, even as they have simultaneously learned to expect less from it.

In 2011 Razlog respondents seemed more positive about the overall health of the local environment than they were in 1999, and a great deal more positive than Bulgarians from the more industrial eastern Bourgas region surveyed in 1992 and 1993. Figure 3 shows that opinion on the quality of the local forest environment has swung nearly 180 degrees, from $73 \%$ mildly or strongly negative to $62 \%$ mildly or strongly positive. In most other questions too respondents were more optimistic in 2011 than they were in 1999. What's more, 1999 respondents were themselves more optimistic than Bulgarians from the Bourgas region surveyed in 1992 and 1993. Overall we contend that whilst environmental conditions may well have improved since 1989, other factors too are responsible for these transformations in perception. Starting in the 1990s Bulgarians began to receive a great deal of information about environmental conditions (previously available only through samizdat and émigré publications). Initially this appears to have caused a general downturn in popular perceptions of environmental quality, but more recently the greater availability of relatively reliable information about the environment, especially that available from non-Bulgarian official sources such as the EC and foreign scientific institutes, seems to have helped support more balanced popular assessments [European Commission 2011]. No doubt Bulgaria's accession to the EU in 2009 helped also, both in terms of bringing the country into a European community with well-established environmental information 
Figure 5. 'Obshtina councils cannot properly manage the environment'

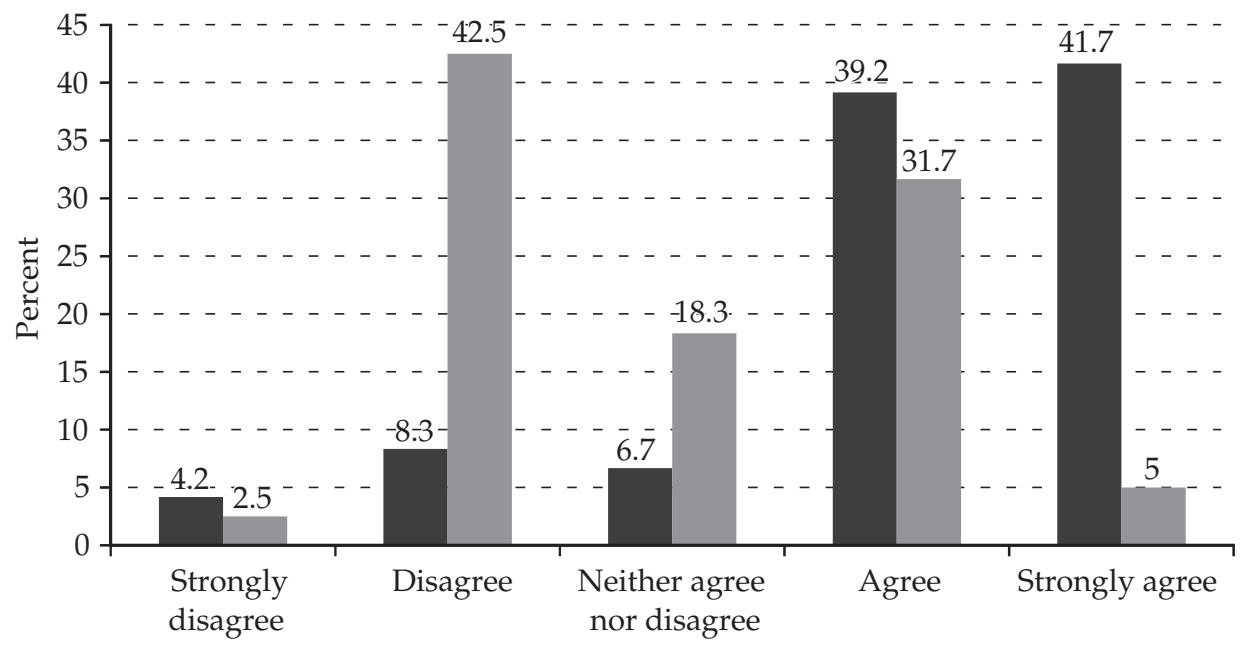

Source: Authors.

19992011

and data standards, but also making the country eligible for regional development and other funds.

These general findings, suggesting a strong desire to conserve and protect local environments, have been replicated in many other opinion surveys around the world [European Commission 2011]. While there is a tendency in the literature to interpret this finding in terms of the cognitive dissonance between proconservationist values and anti-conservationist behaviours we do not see the Bulgarian results in this light at all. We argue instead that in the context within which residents of rural areas like the Razlog Basin find themselves it is not necessarily inconsistent to both treasure the natural environment and to exploit it in multiple and potentially impactful ways (e.g. over-hunting or destruction of mushroom habitat). Nor do we see this as any sort of 'tragedy of the commons' where open access resources as wantonly plundered by individuals with no direct stake in their conservation.

The third theme of the survey probed respondents' views about the respective roles of government, civil society and individuals in nature conservation and resource management. Overall in 2011 we found respondents much more positively inclined towards organisations like the 'Forests Inspectorate' (45\% felt it was doing a good or great job) and 'government' in general. Local government (the 'obshtina' or municipal council) especially was more favourably viewed in 2011 than in 1999 or in 1992 in eastern Bulgaria. There was a markedly higher level of disagreement with negatively framed questions (Figure 5) while simulta- 
Figure 6. 'Nature Protection Groups have a critical role in environmental management'

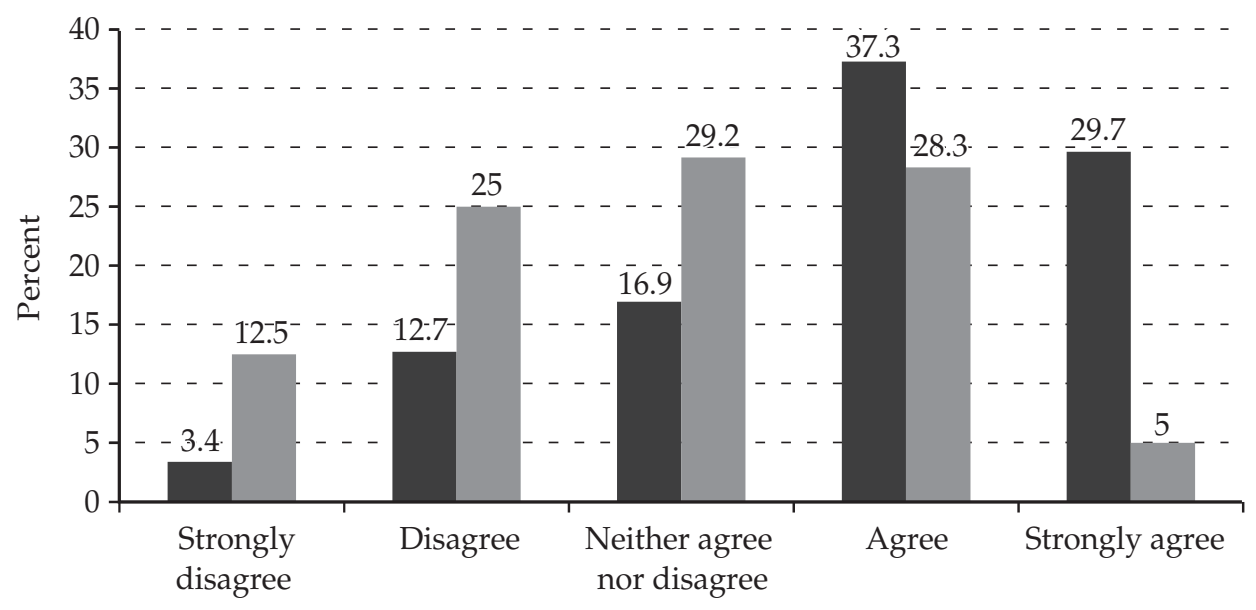

Source: Authors.

neously there appears now to be a more pragmatic view about both the responsibilities of government and its actual capacities. Respondents still tend to the view, especially in hard economic times, that it is the responsibility of government to ensure a basic living standard for citizens (the social welfare function), though this view seems to be leavened with a recognition that other actors too, including private business, civil society and individuals all have a role to play in good governance. ${ }^{4}$ In this sense the Bulgarians surveyed in 2011 appear more like the Poles surveyed in 1999, at least as regards their attitudes and values regarding the responsibilities and actual capacities of government. Twenty-two years and several governments after the regime change initiated in November of 1989 Bulgarians living in the Razlog Basin are clear that one of the main priorities of government is social provision, but they also appear to have a more pragmatic understanding of government's capacity to act. Both our survey and the $2011 \mathrm{Eu}-$ robarometer suggests that these attitudes have hardened relative to other Europeans, perhaps in response to the protracted economic crisis pervading Europe currently.

Similar research conducted by Petrova, Cihar and Bouzarovksi [2011] in the Czech Republic and Macedonia provides an opportunity for brief comparison of results obtained. Patterns of attachment to the proximate national parks (Pelister in Macedonia and Šumava in the Czech Republic) and Pirin in Bulgaria

${ }^{4}$ In some ways our Bulgarian respondents are not so different from British citizens, many of whom have taken refuge in arguments about the 'social welfare function' of government during the current economic crisis. 
seem similar in many ways. Bulgarian respondents seem nearly as positive as Czechs about the national park and the levels of 'exploitation-in-conservation' that the designation implies which may be accounted slightly odd since the patterns of material interaction with the local natural resource hinterlands is more closely aligned with the Macedonian case. It is tempting to posit that perhaps there may be a developmental continuum here, with the Czech case at one end characterised by a more 'Western' perspective that both loves nature and trusts governmental authorities to manage reasonably well and the Macedonian case at the other characterised, as Petrova et al. put it, by a large degree of both ignorance and apathy [Petrova, Cihar and Bouzarovski 2011: 331]. Our Bulgarian respondents fit somewhere in between these two extremes, though we have certainly seen a movement 'westwards' between 1999 and 2011. Unfortunately Petrova et al. do not comment on the potential semantic dissonance that may exist between strong levels of local place attachment and actual expropriative practices.

\section{Determinants of environmental attitudes and behaviours}

In this section we explore further the apparent contradiction introduced in the first section of the paper: to what extent are local people committed to both environmental protection and environmental exploitation and how is this apparent cognitive dissonance managed by respondents? In the previous section we used survey data descriptively and elaborated on basic observations through recourse to more ethnographic data. Here, we have chosen initially to analytically explore the apparent contradiction using eight questions from the survey which asked after perceptions of natural environmental quality (3.1), the respective roles of citizens, local government and community groups in environmental management $(2.2,2.5,3.5)$ and the relations between exploitation versus conservation and job growth $(1.2,1.5,1.6,2.10,3.5)$. These questions are listed below:

1.2 'Local industry unwisely exploits the natural resources of my area'

1.5 'National Park Pirin is economically good for the community'

1.6 'Local natural resources must be exploited more actively to improve the economy'

2.2 'Citizens must not question the decisions of those they elect to public office'

2.5 'Nature Protection Groups have a critical role in environmental management'

2.10 'Too much emphasis is already placed on protecting local forest resources'

3.1 'Forests in my area are in good condition'

3.5 'Nature conservation efforts are harming economic development prospects' 
They were chosen because there appeared to be some differentiation of responses, because they offered potentially cross-cutting approaches to the research question and because they were asked in both 1999 and 2011. We start with a series of scatterplots and bivariate correlations, using Spearman's rank correlation coefficient, designed to test some commonly held ideas about simple determinants of environmental attitudes and behaviours, for example the idea that older people are less conservation-minded than younger people. Interpretation of these results will also draw on socio-economic status results discussed earlier as well as interviews and other 'thicker' forms of ethnographic data.

With respect to questions about the local economy, it is clear from what we have already seen that men are inclined to be slightly more pessimistic about local economic prospects (although both men and women are equally pessimistic about the chance of getting a job), the importance of foreign investment to local economic regeneration and the particular difficulties experienced by young people, and prioritising economic investment, jobs and development as national government priorities. Interviews with business owners, and civic figures, virtually all of whom are men, in the region have shown that there is a general view that little investment is coming to the region from central or regional government, and that the investment that is happening (especially in and around the vastly expanded Bansko ski resort) is the result of crooked business deals. And indeed the economic 'chickens' may be coming home to 'roost' since as of winter 2012-2013 nearly half of the newly-built hotels in Bansko appear to be for sale.

There is a modest tendency, especially amongst women, to interpret the responsibilities of local government in terms of immediate local issues, such as specifically local nature protection, schools, etc., although both men and women are strongly supportive of National Park Pirin. Both men and women are however also supportive of the idea that 'local natural resources must be exploited more actively to improve the economy', and yet also manage to largely disagree that there is 'too much protection of the environment'. Whilst seemingly contradictory, we would argue that the key issue is just who is seen to be doing the managing and who is seen to be doing the exploiting. This follows from the discussion in the previous section. In line with findings elsewhere [e.g. Staddon 2001; Muth and Bowe 1998; Assenov 2010], what people seem to be saying is that they want more commercial exploitation of the local environment, but only if it generates long term local economic benefits and, ideally, is locally-controlled. There is a clear sense that forest extractive activities are, if conducted by local interests, are virtuous and licit, even if technically illegal.

So, are attitudes to the economy and the environment linked to gender, age or SES in a way that is statistically measurable? In fact there is very little correlation between gender and the subset of questions selected for further analysis. There was a slight tendency for men to be more pessimistic about the economy $(r=0.23)$ and optimistic about environmental quality than women $(r=0.2)$, but nothing very strong. As regards age, there was a measurable but modest tendency for older 
people to disagree that that local industry unwisely exploits the environment and to disagree that 'National Park Pirin is good for the economy' ( $r$ of between -0.2 and -0.1 for both). This perhaps sorts well with the slight tendency for older people to think that the environment must be exploited more $(r=0.15)$ and the slight tendency $(r=-0.19)$ to rate the quality of resources higher if you are younger. Correlations between SES, measured by either income or purchase history, and responses to the above subset of survey questions were hardly more encouraging, with 'income' only yielding an $r$ of -0.31 against question 2.2, suggesting, though not very strongly, that the better off tend to be less quiescent about government, possibly because their relative wealth is both an indicator of involvement with and a measure of success in working with the organs of the state. Poorer respondents appear to feel more disenfranchised and therefore more negative. None of these bivariate correlations provide however very much explanatory power even if they are statistically significant. We are left with the impression that gender, age and SES do contribute to attitudes about the economy and the environment, but may be less important than other, perhaps underlying, variables or factors.

We now turn to the results of a few speculative correlation analyses between attitudinal questions themselves. However, if demographic variables don't capture the essence of respondents' decision-making, then perhaps the questions themselves can come closer to defining the underlying factors. The correlation between 1.2 ('local industry unwisely exploits ...') and 1.6 ('local nature resources must be exploited more actively ...' $)$ is poor $(r=0.17)$ and in the wrong direction indicating yet again a certain confusion and/or complexity of attitudes to the environment. One might have expected response patterns to be roughly inversely correlated with one another, yet we discovered a positive, albeit weak, relationship between the two, possibly for semantic reasons-in interviews some respondents have suggested that part of what is meant by 'unwise exploitation' is too little exploitation and/or exploitation that fails to achieve sufficient value added throughout the Green Chain. Respondents also disagreed with 3.5 less strongly than with 2.10, though concordance of responses was better than many correlations so far achieved $(r=0.25)$, suggesting that there is a core of attitudes which are not gender, age or SES specific characterised by the desire to see more active exploitation of natural resources and by worries about the constricting effects of nature protection. We are thus revealing an identifiable core of demographically diverse local people who believe that there ought to be more, or more efficient, nature exploitation. They appear to both value their local environment and depend upon it for their livelihoods, and therefore see exploitation from a pragmatic point of view. Much less evident is the common urban middle class value system found elsewhere in Europe which values a (more abstract) version of nature and seeks to curtail industrial exploitation of it [European Commission 2011].

It is not uncommon at this stage in the analysis of survey data to turn away from simpler bivariate correlational analysis and towards more sophisticated multivariate analysis. Very often multiple regression is used to test the possibility 
that each of several independent variables may explain a portion of the variation in a dependent variable. In the current case it is reasonable to wonder whether the attitudes described in the above subset of questions may be better explained in terms of their relationships with multiple factors such as age, sex, income class and level of education. Though there is insufficient space to explore this methodology in any detail here, we did create a number of regression models (using logit regression as better befits ordinal data) but did not find that we were able to explain a significantly greater portion of the variation in any of the dependent variables. Alternative analytical paths may involve the exploration of the potential of different multivariate methodologies, including CART and factor analysis.

As regards the central contradiction we sought to examine in this paper, between 'nature-love' and 'nature exploitation' we have seen that there is a slight tendency for older women to be less sentimental about the local environment and that better off, better educated, households are more sanguine about the environment, government and local economic prospects. However the absence of strong correlations (defined as $r$ values greater than $+/-0.5$ through bivariate or multivariate techniques) suggests that sentimental and utilitarian impulses are manifest in most of our respondents and are not easily explained by age, gender, or any of several measures of SES. Previous ethnographic research in the locality supports this view, suggesting that local respondents deploy different specific attitudes to the environment 'tactically' or 'situationally'. Consequently, given purely abstract statements (e.g. 'National Park Pirin is good for the local econo$\mathrm{my}^{\prime}$ ) to react to, respondents find it easy to agree strongly, even if they also agree strongly with statements like 'nature conservation efforts are harming economic development prospects'. In interviews the apparent contradiction is resolved by interviewees explaining different specific circumstances in which both statements may be worthy of support. This is in line with other research into environmental attitudes and behaviours which has found that key determinants include, but cannot be reduced to, attitudinal factors, personal capabilities (such as financial situation), habits or routines, and contextual forces. As we noted in the introduction to the paper, various sorts of extraneous bias may also be at play here, further complicating the interpretative task.

\section{Conclusion}

The general objective of this paper was to present a preliminary analysis of recent survey results exploring community-environment relations in a single locality in the uplands of southwest Bulgaria. Though the most recent survey of environmental attitudes and values was only completed in September 2011 we have been able to quickly identify a number of key findings:

- respondents are more optimistic about the role of government than they were in 1999 or 1992; 
- respondents are more positive about the health of the natural environment than they were in 1999 or 1992;

- respondents are still relatively passive and non-committed in terms of their own personal involvement in environmental governance or indeed in officially sanctioned 'green' behaviours such as recycling;

- although respondents value them, there is some cynicism about the effectiveness of environmental NGOs 'on the ground' in the Razlog Basin;

- difficult economic conditions have meant that there is still a strong, though decreasing, reliance on directly collected foodstuffs and fuel wood from local forests and agricultural holdings.

It is interesting to note that these results slot nicely in between the more apathetic and distanced attitudes expressed by Macedonians and the more engaged and optimistic attitudes expressed by Czechs presented in a recent study by Petrova, Cihar and Bouzarovski [2011] and Poles in a study by Grykeiń and Staddon [2007]. Over time Bulgarian attitudes and behaviours, in our study region at any rate, seem to be 'Westernising' or perhaps 'Europeanising', given the convergence with attitudes expressed in the recurring Eurobarometer surveys [European Commission 2011].

Overall we judge that Bulgarian attitudes are to a significant degree 'Europeanising', but are doing so in a uniquely national, and even sub-national, way. General environmental attitudes are clearly inflected through local perceptions and behaviours to create a situation whereby there is in some cases a significant cognitive distance between overall environmental attitudes and local environmental attitudes. A key area where the Europeanisation (rather than globalisation/neoliberalisation) of attitudes is apparent is in the strong adherence to a more social democratic model of state-society relations than implied by the global (neoliberal) consensus. Bulgarians, at least in the Razlog Basin, want their government to intervene in their lives, but to intervene in a way that promotes local development and economic health and prevents social deprivation. With respect to environmental attitudes we see a strong endorsement of the role of central and especially local government in environmental management. What's more, respondents clearly expect their regulatory authorities to balance nature-exploitative activities (such as forestry) and nature-conservative activities (such as national parks designation). Nature tourism activities sit somewhere in the middle of all this not least because certain kinds of nature tourism such as ski resort development (read: Bansko) can be as damaging as industrial forestry but also provide for employment, albeit at relatively lower wages, at useful times of the year.

A related objective was to explore the apparent contradiction between 'nature-loving' and 'nature-exploitative' attitudes amongst residents of the Razlog Basin. So far we have found that this contradiction exists across gender, age and SES class divides and this accords well with research elsewhere [Diamantopolous et al. 2003]. It therefore cannot be said that particular attitudes adhere to easily identifiable subsets of the local population such as the 'young', the 'old', or 
the 'poor'. Instead we are inclined to the view that both ideals, though apparently contradictory, exist in the minds of the majority of our respondents and are deployed contextually. This is not an appeal to an hypostatised sense of scale hierarchy however since there is no sense in which 'national' perceptions or attitudes predetermine regional or local ones. There is no single, uniform, national attitude towards the environment, but rather a number of competing discourses jostling for attention. Any perceived scale relations are apparent only. Thus, whilst an over-arching and very abstract sense of 'nature-love' can be displaced by the view that local forest resources ought to be exploited more ruthlessly in order to generate needed employment it can also underwrite a more profoundly conservationist politics. Conversely, those with an abiding sense of 'nature-utilitarianism' can and do express more strongly conservationist attitudes when local natural resources are at stake, as for example during the expansion of the Bansko ski resort in the early 2000s [cf. Staddon and Cellarius 2002]. From the point of view of critical political ecology, a key problem is that tenure relations in natural resources are too manifold and variegated to permit of any single scale hierarchy in attitudes and behaviours.

Ultimately we suggest that the paradox with which we started is not really a paradox at all, but merely part of the irreducible complexity of environmental attitudes and values manifest in all complex social systems. Put another way: our respondents do not hold only one view on issues such as local development or nature protection. Rather, they hold a range of views which, when seen in isolation, can sometimes seem contradictory, but which are more coherent when seen holistically. Thus, the potential for cognitive dissonance, so apparent to social researchers working with only crude snapshots of the populations they study, often does not even arise for respondents themselves. The paradox may not be a paradox after all.

CHAD STADDON received his PhD in geography from the University of Kentucky in 1996 for research on the political economy of water (mis)management in post-communist Bulgaria. In 1996 Chad joined the Department for Geography \& Environmental Management at the University of the West of England, Bristol and is now Associate Professor in Geography and Founder-Director of the Bristol Group for Water Research. His current projects, funded by the European Commission's Seventh Framework and the Lloyd's Register Foundation involve cross-national studies of water management regimes, and in particular water services provision, at the urban scale.

SteFAn GeNCHev was awarded a bachelor degree in geography from Sofia University 'St. Kliment Ohridski' in 2008. In 2013 he will complete his programme to obtain a master's degree in economics. Since 2010 he has been working in NIGGG-BAS as a Geographer. His recent particular interests are focused on the economic advantages of the application of GIS in the public and private sectors. Another part of his range of research interest is the application of GIS in management, control and prevention of flood risk. 


\section{References}

Assenov, Assen. 2010. 'Willingness of the Population of Satovcha Municipality to Pay for Ecosystem Services.' Proceedings of the 6th International Conference on Global Changes and Regional Development: 29-53. Sofia: Bulgarian Academy of Sciences.

Begg, R. and J. Pickles. 1998. 'Institutions Social Networks and Ethnicity in the Cultures of Transition: Industrial Change Mass Unemployment and Regional Change in Bulgaria.' Pp. 115-146 in Theorising Transition: The Political Economy of Post-communist Transition, edited by J. Pickles and A. Smith. London: Routledge.

Bell, John D. 1977. Peasants in Power: Alexander Stamboliski and the Bulgarian Agrarian National Union, 1899-1923. Princeton, NJ: Princeton University Press.

Biondich, Mark. 2011. The Balkans: Revolution, War, and Political Violence since 1878. Oxford: Oxford University Press.

Blaikie, Piers and Harold Brookfield. 1987. Land Degradation and Society. London: Methuen.

Bridger, Sue and Frances Pine (eds.). 1998. Surviving Post-socialism: Local Strategies and Regional Responses in Eastern Europe and the Former Soviet Union. London: Routledge.

Bryant, Raymond L. and Sinead Bailey. 1997. Third World Political Ecology. London: Routledge

Burawoy, Michael and Katherine Verdery (eds.). 1999. Uncertain Transition: Ethnographies of Change in the Post-socialist World. London: Rowman and Littlefield.

Burton, Dawn (ed.). 2000. Research Training for Social Scientists. London: Sage.

Carter, Francis. W. and David Turnock (eds.). 2002. Environmental Problems of East-Central Europe. 2nd ed. London: Routledge.

Cellarius, Barbara A. 2001. 'Seeing the Forest for the Trees: Local-Level Resource Use and Forest Restitution in Postsocialist Bulgaria'. GeoJournal 55 (2-4): 599-606.

Cellarius, Barbara A. 2004. In the Land of Orpheus: Rural Livelihoods and Nature Conservation in Postsocialist Bulgaria. Madison, WI: University of Wisconsin Press.

Crampton, R. 1997. A Concise History of Modern Bulgaria. Cambridge: Cambridge University Press.

Diamantopoulos, Adamantios, Bodo Schlegelmilch, Rudolf Sinkovics and Greg Bohlen. 2003. 'Can Socio-demographics Still Play a Role in Profiling Green Consumers? A Review of the Evidence and an Empirical Investigation.' Journal for Business Research 56 (6): 465-480.

European Commission. 2011. Attitudes of European Citizens toward the Environment. Special Eurobarometer 365. Brussels: European Commission.

European Commission. 2013. 'Gross Domestic Product at Current Prices.' Retrieved 2 May 2013 (http://epp.eurostat.ec.europa.eu/portal/page/portal/national_accounts/ data/main_tables).

Eurostat. 2013. 'European Macroeconomic Indicators.' Eurostat Online Database. Retrieved 27 April 2013 (http://epp.eurostat.ec.europa.eu/portal/page/portal/ eurostat/home).

Forsyth, Tim. 2003. Critical Political Ecology: The Politics of Environmental Science. London: Routledge.

Grunewald, Karsten and Jörg Scheithauer. 2011. Landscape Development and Climate Change in Southwest Bulgaria (Pirin Mountains). Berlin: Springer Verlag.

Grykień, Stanislaw and Chad Staddon. 2007. 'Community-Environment Interactions in Postcommunist Restructuring: Bulgaria and Poland.' Natural Determinants of Rural Area Development. Warsaw: Polish Academy of Sciences. 
Kostova, Zdravka, Elka Vladimirova and Blagovesta Radoynovksa. 2011. 'The Environmental Concern of Ninth-Grade Students from a Secondary Professional School.' Bulgarian Journal of Science and Education Policy 5 (2): 178-218.

Low, Setha M. and Irwin Altman. 1992. 'Place Attachment: A Conceptual Inquiry.' Pp. 1-12 in Place Attachment, edited by I. Altman and S. M. Low. New York: Plenum Press.

McCullagh, Peter. 1980. 'Regression Models for Ordinal Data.' Journal of the Royal Statistical Society 42 (2): 109-142.

Marston, Sally A., John P. Jones III and Keith Woodward. 2005. 'Human Geography without Scale.' Transactions of the Institute of British Geographers 30 (4): 416-432.

Massey, Doreen 2001. 'Living in Wythenshawe.' Pp. 459-475 in The Unknown City: Contesting Architecture and Social Space, edited by I. Borden, J. Kerr, J. Rendell and A. Pivaro. Cambridge, MA: MIT Press.

Mirovitskaya, Nataliya. 1998. 'The Environmental Movement in the Former Soviet Union.' Pp. 30-66 in Environment and Society in Eastern Europe, edited by A. Tickle and I. Welsh. Harlow: Longman.

Moldan, Bedrich and Jurg Klarer. 1997. The Environmental Challenge for Central European Economies in Transition. Oxford: Wiley-Blackwell Books.

Muth, Robert M. and John F. Bowe. 1998. 'Illegal Harvest of Renewable Natural Resources in North America: Toward a Typology of the Motivations for Poaching.' Society and Natural Resources 11 (1): 9-24.

Naidenova, R. (ed.) 1990. Prirodniyat i Ikonomicheskiyat Potentsial na Planinite v Bulgaria, tom 2. (Natural and Economic Potential of the Mountains of Bulgaria, volume 2) Sofia: Bulgarian Academy of Sciences.

Nash, Roderick. 1967. Wilderness and the American Mind. New Haven, NJ: Yale University Press.

Oldfield, Jonathan. 2006. Russian Nature: Exploring the Environmental Consequences of Societal Change. Aldershot: Ashgate Books.

Peterson, David J. 1993. Troubled Lands, the Legacy of Soviet Environmental Destruction. Boulder, CO: Westview Press.

Petrova, Saska, Martin Cihar and Stefan Bouzarovski. 2011. ‘Local Nuances in the Perception of Nature Protection and Place Attachment: a Tale of Two Parks.' Area 43 (3): 327-335.

Pickles, John and Chad Staddon. 1994a. 'Perceptions of Environment, Well-Being and Governance in Bourgas and Kameno Obshtini, June 1992.' Research Paper 9417. Morgantown: Regional Research Institute, West Virginia University.

Pickles, John and Chad Staddon. 1994b. 'Attitudes about Governance and Environmental Issues in Bourgas and Kameno Obshtini, July 1993.' Research Paper 9413. Morgantown: Regional Research Institute, West Virginia University.

Staddon, Chad. 1999. 'Economic Marginalisation and Natural Resource Management in Eastern Europe'. Geographical Journal 165 (2): 200-208.

Staddon, Chad. 2001. 'Local Forest Dependence in Postcommunist Bulgaria: A Case Study.' Geojournal. Special issue 'Community Level Response to Post-Communist Transformations' 55 (2-4): 517-527.

Staddon, Chad. 2005. 'Working with the Grain?: FDI in the Bulgarian Woodworking Sector.' Pp. 225-242 in Foreign Direct Investment and Regional Development in East Central Europe and the Former Soviet Union: A Collection of Essays in Memory of Professor Francis 'Frank' Carter, edited by D. Turnock. Aldershot: Ashgate Press.

Staddon, Chad. 2009. 'Towards a Critical Political Ecology of Human-Forest Interactions in Bulgaria.' Transactions of the Institute of British Geographers 34 (2): $1-17$. 
Staddon, Chad and Barbara Cellarius. 2002. 'Paradoxes of Conservation and Development in Postcommunist Bulgaria: Recent Controversies.' European Environments 12 (2): 105-116.

Staddon, Chad and Stanislaw Grykień. 2007. 'The Meaning of Forests in the Klodzko Powiat Economy.' Studia obszarow wiejskich 12 (2007): 141-150.

Staddon, Chad and Stanislaw Grykień. 2009. 'Local Forest Dependence in Central Eastern Europe: Bulgaria and Poland.' Annuaire roumain d'anthropologie 46: 107-119.

Staddon, Chad, John Pickles and Petr Pavlínek. 1998 `Who Cares about the Environment? Popular Attitudes to Pollution and Environmental Reconstruction: Two Case Studies from Bulgaria and Czech Republic.' Pp. 229-256 in Bulgaria in Transition: Environmental Consequences of Political and Economic Transformation, edited by K. Paskaleva, P. Shapira, J. Pickles and B. Koulov. Aldershot: Ashgate.

Staddon, Chad and David Turnock. 2001 'Social Justice and the Environmental Costs of Transition: Environmental Geographies of Post-communist Transition.' Pp. 231-246 in Environment and Society in Eastern Europe and the Former Soviet Union, edited by D. Turnock. Cheltenham: Edward Arnold.

Stanners, David and Philippe Bourdeau. 1995. Europe's Environment: The Dobris Assessment. Brussels: European Environment Agency.

Stern, Paul. 2000. 'Toward a Coherent Theory of Environmentally-Significant Behaviour' Journal of Social Issues 56 (3): 407-424.

Tuan, Yi-Fu. 1977. Space and Place: The Perspective of Experience. Minneapolis, MN: University of Minnesota Press.

de Vaus, David. 2002. Analyzing Social Science Data: 50 Key Problems in Data Analysis. London: Sage Publications.

Veen, Peter, Josef Fanta, Ivan Raev, Iovu-Adrian Biriş, Jacques de Smidt and Bert Maes. 2010. 'Virgin Forests in Romania and Bulgaria: Results of Two National Inventory Projects and Their Implications for Protection.' Biodiversity $\mathcal{E}$ Conservation 19 (6): 1805-1819.

Winchester, Hilary. 1999. 'Interviews and Questionnaires as Mixed Methods in Population Geography: the Case of Lone Fathers in Newcastle, Australia.' The Professional Geographer 51 (1): 60-67. 